\title{
Natural flow regime, degree of alteration and environmental flows in the Mula stream (Segura River basin, SE Spain)
}

\author{
Óscar Belmar ${ }^{1, *}$, Josefa Velasco ${ }^{1}$, Francisco Martínez-Capel ${ }^{2}$ and Antonio Alberto Marín ${ }^{2}$ \\ ${ }^{1}$ Departamento de Ecología e Hidrología, Facultad de Biología, Universidad de Murcia, Campus de Espinardo, \\ 30100, Murcia. \\ ${ }^{2}$ Instituto de Investigación para la Gestión Integrada de las Zonas Costeras, EPS de Gandía, Universidad \\ Politécnica de Valencia, Camino de Vera, s/n, 46022, Valencia. \\ * Corresponding author: oscarbd@um.es
}

Received: $14 / 9 / 09 \quad$ Accepted: $15 / 6 / 10$

\begin{abstract}
Natural flow regime, degree of alteration and environmental flows in the Mula stream (Segura River basin, SE Spain)

The Mula stream, a tributary located in the southern part of the Segura River basin, possesses habitats and species of European interest for which it has been declared Special Area of Conservation (SAC) within the Natura 2000 network. However, strong agricultural pressures on the superficial and groundwater resources of the Mula stream are threatening its ecological state. A characterisation of the natural flow regime of the stream and its main tributaries was carried out to design environmental flow regimes (EFRs) and make the conservation of the ecosystem compatible with agricultural requirements. Natural hydrographs, based on daily data corresponding to pre-dam periods, showed a high inter- and intra-annual variability typical of Mediterranean streams, with high flows in autumn and spring and low flows in summer. After the construction of the $L a$ Cierva reservoir in the Mula stream, the flow regime has been progressively altered in parallel with the expansion of irrigated agriculture in the watershed. The current regime shows a significant reduction in the magnitude of flows and a reversal of the seasonal pattern, with droughts during winter instead of summer months becoming more frequent and long-lasting. Different EFRs are presented for three conservation scenarios of natural flow regimes in wet, average and dry years. Once the environmental flows were subtracted from the natural ones, the available water resources for agriculture were clearly insufficient in all studied scenarios, which poses problems for the implementation of such environmental flows in this basin.
\end{abstract}

Key words: Natural flow regime, environmental flows, hydrologic alteration, water management, Mula stream, Segura River basin.

\section{RESUMEN}

Régimen natural de caudal, grado de alteración y caudales ambientales en el río Mula (cuenca del río Segura, SE de España)

El Río Mula, un afluente localizado en la parte meridional de la cuenca del Río Segura, posee una elevada riqueza de hábitats de interés comunitario por los que ha sido declarado LIC dentro de la Red Natura 2000. Sin embargo, la fuerte presión agrícola sobre sus recursos superficiales y subterráneos amenaza su estado ecológico. En este estudio se ha llevado a cabo una caracterización del régimen natural de caudales del río y sus principales afluentes con el fin de diseñar Regímenes Ambientales de Caudales (RACs) y hacer la conservación del ecosistema fluvial compatible con las demandas agrícolas. Los hidrogramas naturales, obtenidos a partir de registros diarios de aforos correspondientes a periodos previos a la construcción de embalses, mostraron una alta variabilidad inter e intranual típica de los ríos mediterráneos, con altos caudales en otoño y primavera y bajos en verano. Tras la construcción del embalse de La Cierva en el Río Mula el régimen de caudales ha sido alterado progresivamente en paralelo a la expansión de la agricultura de regadío en la cuenca. El régimen actual muestra una reducción significativa en la magnitud de los caudales y una inversión del patrón estacional, es decir, sequías en invierno en lugar de en verano y cada vez más frecuentes y duraderas. Se presentan los diferentes RACs estimados para tres escenarios de conservación de los regímenes naturales de caudal, tanto para años húmedos como para medios y secos. En todos los escenarios estudiados, los recursos hídricos disponibles para la agricultura, previa detracción de los caudales ambientales, son claramente insuficientes, lo que dificulta la implementación de dichos caudales ambientales en esta cuenca. 
Palabras clave: Régimen natural de caudales, caudales ambientales, alteración hidrológica, gestión del agua, Río Mula, cuenca del Río Segura.

\section{INTRODUCTION}

The natural regime defines the hydrological variability pattern and reflects the interaction between the climatic regime (precipitation and temperature) and the basin characteristics that regulate runoff (geomorphology, geology and vegetation). The structure and function of river ecosystems are strongly affected by natural flow regimes because the biota is adapted to its components. These components are defined as: magnitude, frequency, duration, rate of change and predictability of flow events (Lytle \& Poff, 2004).

Human activities alter natural flow regimes both directly and indirectly, with impacts on biological communities, energy flows, nutrient and sediment dynamics and the interaction with the floodplain (Poff et al., 1997; Magdaleno, 2005; Poff \& Zimmerman, 2010). One of the most significant alterations occurs when a dam is built. The general effect is the transformation of dynamic patterns into static, relatively stable patterns with reduced flows (Stanford \& Ward, 1979; Baeza et al., 2003; Benejam et al., 2010). This change is especially evident in the case of the Segura River basin, which is one of the most regulated basins in Spain (24 large dams, one per each $50 \mathrm{~km}$ of channel) (Confederación Hidrográfica del Segura, 2007). Water abstraction and flow regulation, mostly for irrigation purposes, have considerably reduced flows and have caused serious changes in natural seasonal variation, specially during floods and droughts (Vidal-Abarca \& Suárez, 2007). This is often accompanied by inverse patterns in the variation of downstream dam flows, with the highest water levels in the summer months and the lowest in winter (Vidal-Abarca et al., 2002).

In the context of the Water Framework Directive (WFD, 2000/60/EC), establishing environ- mental flow regimes that take into account the natural hydrological variability is of vital importance for the protection and improvement of the ecological status of water masses. The revised text of the Spanish Water Law (Royal Decree 1/20/7/2001), which implements WFD, explicitly states that Basin Management Plans must include the environmental flow regime for each body of water, with priority given to protected zones. The environmental flow regimes will be necessary "to maintain or re-establish the proper state of conservation of habitats or species, meeting their ecological requirements and maintaining the long-term ecological functions they depend on." Additionally, the ecological flow regime must include the time distribution of maximum and minimum flows, flood and drought flows and the rates of flow change (Hydrological Planning Instruction, ORDEN ARM/2656/22/9/2008).

The Mula watershed is one of the areas of highest conservation interest in the Segura basin, with $37 \%$ of its territory in the Natura 2000 network (25\% as Special Protection Areas (SPAs) for birds, $2 \%$ as Special Areas of Conservation (SACs) and $10 \%$ as both) and $110 \mathrm{~km}$ of protected stream channels (Fig. 1). Agriculture is one of the most important activities in the area, with non-irrigated crops occupying $46 \%$ of the land, and irrigated crops covering another $11 \%$ (as calculated from Corine Land Cover 2000). Water irrigation demands exceed the naturally available superficial runoff; as a result, there is now a strong dependence on aquifers and water transferred from the Tagus River. The present and future impact of this excessive pressure on water resources threatens the important habitats and species for which these streams were declared SACs.

The aim of the present study was to characterise the natural flow regimes of the Mula stream and its main tributaries, to determine the extent 


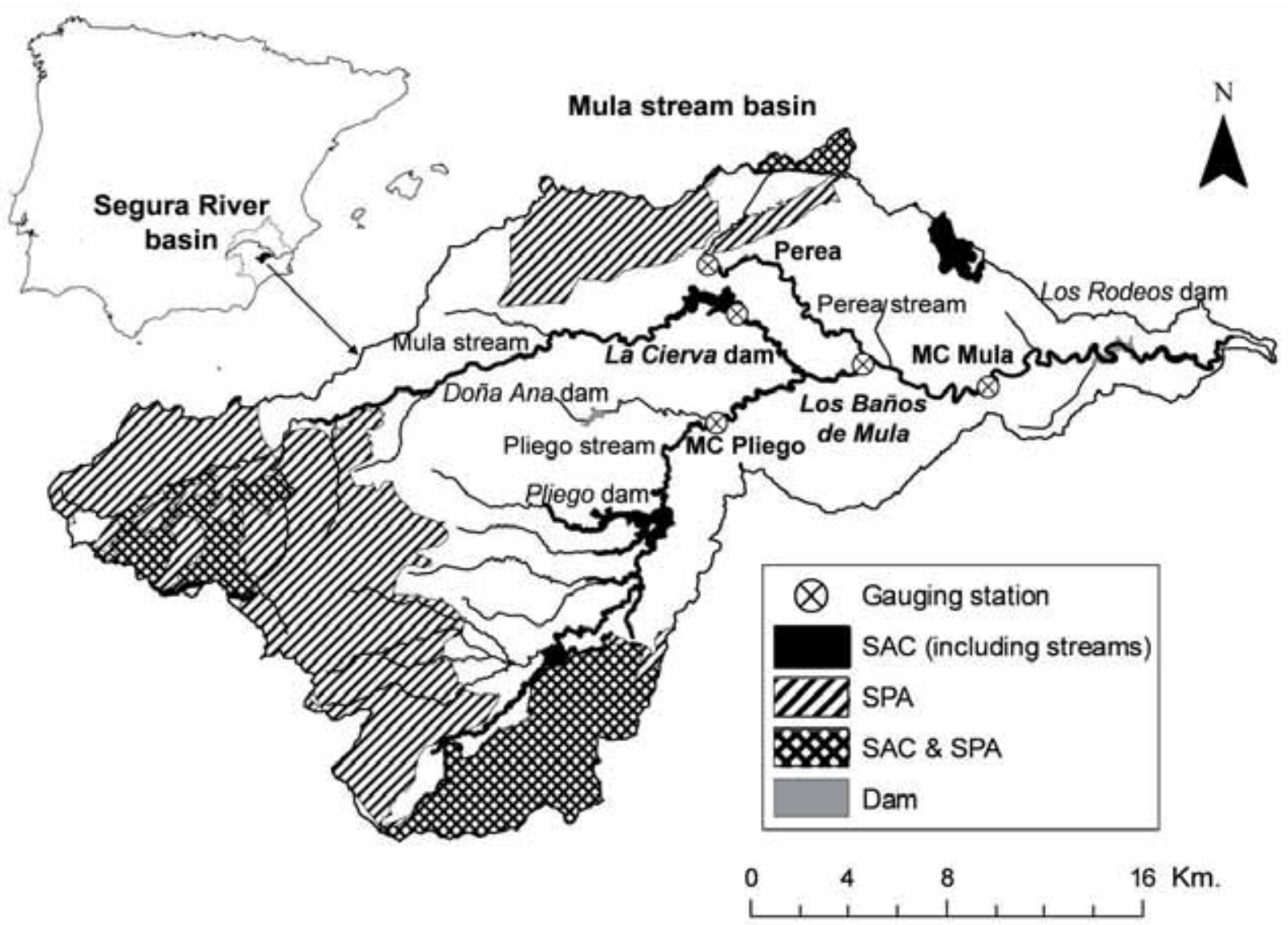

Figure 1. Geographic location of the Mula stream basin, hydrologic network with the location of dams, gauging stations and Natura 2000 areas. Localización geográfica de la Cuenca del río Mula, red hidrológica con la localización de las presas, estaciones de aforo y áreas Natura 2000.

of its alteration and to design environmental flow regimes to protect aquatic habitats and species, providing water for irrigation.

\section{MATERIAL AND METHODS}

\section{Study Area}

Within the geographical framework of the Segura River basin, the Mula watershed (Fig. 1) forms a transition area between the warm and arid southeast and the cooler and humid northwest. Mean annual temperature reaches $16^{\circ} \mathrm{C}$; the monthly average is $8^{\circ} \mathrm{C}$ during the coldest month (January) and $25^{\circ} \mathrm{C}$ during the hottest (July). Annual precipitation is around $300 \mathrm{~mm}$, with peaks in April and October and great inter- and intraannual variations, which are typical of Mediterranean regions (Gómez-Espín et al., 2006).

The Mula stream watershed, with an area of $660 \mathrm{~km}^{2}$, is a tertiary colmation basin predominantly formed of impervious marls and clays that, combined with steep slopes and little vegetation, accentuate the torrential effect of precipitation (López-Bermúdez, 1972). Important karstic areas in the headwaters control groundwater storage and feed the Mula springs, which are currently dry due to overexploitation of the aquifer. In relation to the climatic and geologic characteristics of the watershed, the hydrologic network is composed of permanent stream sections in the headwaters and permanent and intermittent sections downstream, with relatively high levels dur- 
Table 1. Climatic and morphometric variables of the different watersheds in the Mula basin. Variables climáticas y morfométricas de las diferentes subcuencas de la Cuenca del río Mula.

\begin{tabular}{lcccc}
\hline \multicolumn{1}{c}{ Variable } & $\begin{array}{c}\text { Mula stream (junction } \\
\text { with Pliego stream) }\end{array}$ & Pliego stream & Perea stream & Mula basin \\
\hline Temperature $\left({ }^{\circ} \mathrm{C}\right)$ & 15.9 & 15.8 & 16.9 & 16.2 \\
Precipitation $(\mathrm{mm})$ & 367.0 & 387.8 & 334.8 & 362.0 \\
Precipitation concentration index (October) & 16 (Seasonal) & 16 (Seasonal) & $16($ Seasonal) & $16($ Seasonal) \\
Area $\left(\mathrm{km}^{2}\right)$ & 186.3 & 275.8 & 55.2 & 660.0 \\
Karstic area $\left(\mathrm{km}^{2}\right)$ & $106.1(57 \%)$ & $145.4(53 \%)$ & $13.4(24 \%)$ & $309.7(47 \%)$ \\
Average altitude $(\mathrm{m})$ & 700.4 & 619.5 & 508.0 & 557.1 \\
Average slope $(\%)$ & 18.2 & 21.1 & 10.6 & 17.4 \\
Stream order $($ Strahler) & 2 & 3 & 3 \\
\hline
\end{tabular}

ing spring and autumn and low levels or null flows in summer. Downstream of La Cierva dam, the Mula stream receives flows from the Pliego stream, its largest tributary, which is more karstic in origin and has a larger drainage area than the upstream portion of the Mula (Table 1). Further downstream, at Baños de Mula, the Mula receives water from hot springs and the Perea stream (Fig. 1). Upwelling groundwaters from the $\mathrm{Ca}-$ puta spring feed the Perea stream in the headwaters. Below the source, there are two weirs; the first provides water for irrigation, and the second channels flash flood runoff to La Cierva reservoir.

The most important event in the agricultural history of the Mula basin was the construction of La Cierva reservoir in 1929. Afterwards, there was a significant change in the use of the natural water resources, including a great expansion of irrigated lands and increased water demands (Table 2). In the second half of the 20th century, there was an intensification of agricultural activities and an increase in irrigation infrastructures; this was due to a shift from nonirrigated to irrigated agriculture such as citrus and other fruit crops (Gómez-Espín et al., 2005) and water transfers from the Tagus River to the Segura River, which began in 1981. In 1985, the Irrigation Modernization Plan was implemented, which increased the regulation capacity of $L a$ Cierva reservoir (up to $7 \mathrm{hm}^{3}$ ), created new reservoirs out of the stream channel and integrated the management of superficial water, groundwater and transferred water from the Tagus River, a process that lasted almost a decade (Navarro, 2007). Recently, more than $50 \%$ of the irrigation water used in the basin has been transferred from the Tagus River (Gómez-Espín et al., 2005).

In addition to La Cierva reservoir, there are three other reservoirs in the stream channel: Pliego, Doña Ana and Los Rodeos. Designed to

Table 2. Evolution of agricultural area during the $20^{\text {th }}$ century in the Mula basin. Evolución de la superfície agrícola de la Cuenca del río Mula durante el siglo XX.

\begin{tabular}{|c|c|c|c|}
\hline Date & Source & Non-irrigated (ha) & Irrigated (ha) \\
\hline 1933 & $\begin{array}{c}\text { Dirección de Obras Hidráulicas del Segura } \\
\text { (Gómez-Espín et al., 2005) }\end{array}$ & & 2111 \\
\hline 1977 & $\begin{array}{c}\text { Mapa de Cultivos y Aprovechamientos del Suelo 1:50.000 } \\
\text { (Ministerio de Medio Ambiente y Medio Rural y Marino) }\end{array}$ & 27452 & 5637 \\
\hline 1990 & $\begin{array}{l}\text { Corine Land Cover 1:100.000 } \\
\text { (European Environment Agency) }\end{array}$ & 33387 & 5232 \\
\hline 2000 & $\begin{array}{l}\text { Corine Land Cover 1:100.000 } \\
\text { (European Environment Agency) }\end{array}$ & 30887 & 7402 \\
\hline
\end{tabular}


Table 3. Gauging stations and data series used for the characterisation of the natural and altered flow regimes. Estaciones de aforo y series de datos utilizadas para la caracterización de los regímenes natural y alterado.

\begin{tabular}{|c|c|c|c|c|c|c|}
\hline \multirow[b]{2}{*}{ Gauging station } & \multirow[b]{2}{*}{ Location } & \multirow[b]{2}{*}{ Code } & \multicolumn{4}{|c|}{ Time series } \\
\hline & & & Natural Altered 1 & Altered 2 & Altered 3 & Altered 4 \\
\hline La Cierva dam & Mula stream & 7019 & $1913-1927$ 1929-1959 & $1961-1980$ & 1981-1992 & 1993-2006 \\
\hline MC Pliego & Pliego stream & 01002 & $2000-2008$ & & & \\
\hline Los Baños de Mula & Mula stream (after Pliego stream) & 7020 & $1913-19271929-1943$ & & & \\
\hline Perea & Perea stream (Caputa spring) & 7042 & $1942-1971$ & & & \\
\hline MC Mula & Mula stream (after Pliego and Perea streams) & 01003 & $2000-2008$ & & & \\
\hline
\end{tabular}

contain floodwaters, these reservoirs were constructed between 1993 and 2000 with regulation capacities of 10,3 and $14 \mathrm{hm}^{3}$, respectively.

\section{Data analysis}

Natural flow regimes were characterised from historical daily flow series recorded at gauging stations in the Mula stream before the building of the dam (downstream of La Cierva reservoir), downstream from the confluence of the Pliego stream (at Los Baños de Mula) and in the headwater of the Perea stream (Caputa spring) (Fig. 1, Table 3). Altered flow regimes were characterised for the Mula stream from the building of the dam to the present in four agricultural development stages: 1929-1959 (after the building of La Cierva dam), 1961-1980 (development of irrigation infrastructures), 1981-1992 (Tagus River transfer) and 1993-2006 (Irrigation Modernization Plan). However, for the Pliego stream, only a small amount of data was available for the altered regime after the construction of its dam (Table 3). Time series were obtained from the Centre for Studies and Experimentation of Public Works (CEDEX) (http://hercules. cedex.es/anuarioaforos) and the Automatic Hydrological Information System of the Segura basin (http://www.chsegura.es/chs/cuenca/redesdecontrol/SAIH/). To describe the natural flow regime and evaluate the degree of alteration, the Indices of Hydrological Alteration in Rivers (Martínez \& Fernández, 2006a) were used via the IAHRIS software (available at http://www.forestales.upm.es/unidad_enlaces.aspx?id=5). This software calculates 24 hydrologic metrics (7 for habitual flows, 9 for high flows and 8 for low flows) that adequately describe the hydrologic regime of Mediterranean streams, including the magnitude, frequency, variability, seasonality and duration of hydrologic extremes (floods and droughts). The degree of alteration in each indicator ( 0 : maximum alteration, 1 : minimum alteration) is established by dividing its value in regulated conditions by the indicator value in natural conditions.

The EFRs were estimated following the methodology proposed by Martínez and Fernández (2006b) for wet, average and dry years using the $25^{\text {th }}$ and $75^{\text {th }}$ percentile boundaries for the annual runoffs. For each type of year and month, the habitual environmental runoff $\left(\left(R_{\text {month_i_ }}^{\mathrm{EFR}}\right)_{W, A, D}\right)$ was obtained from the annual minimum under natural conditions $\left(\left(R_{\min }^{\mathrm{NAT}}\right)_{W, A, D}\right)$ using the following equation:

$$
\left(R_{\text {month_i }}^{\mathrm{EFR}}\right)_{W, A, D}=\left(R_{\text {min }}^{\mathrm{NAT}}\right)_{W, A, D} \times\left(F_{\text {month_i }}^{\mathrm{EFR}}\right)_{W, A, D}
$$

For this equation, $\left(\left(F_{\text {month_i }}^{\mathrm{EFR}}\right)_{W, A, D}\right)$ is the environmental variability factor, which is calculated as a function of the natural variability factor $\left(\left(F_{\text {month_i }}^{\mathrm{NAT}}\right)_{W, A, D}\right)$ and $m$, a coefficient that represents the degree of conservation of the natural flow regime (more protective as its value is closer to 1 , the minimum allowed by definition).

$$
\begin{aligned}
& \left(F_{\text {month_i }}^{\mathrm{EFR}}\right)_{W, A, D}=\left(F_{\text {month_i }}^{\mathrm{NAT}}\right)_{W, A, D}^{1 / m} \\
& \left(F_{\text {month_i }}^{\mathrm{NAT}}\right)_{W, A, D}=\frac{\left(R_{\text {month_i }}^{\mathrm{NAT}}\right)_{W, A, D}}{\left(R_{\text {min }}^{\mathrm{NAT}}\right)_{W, A, D}}
\end{aligned}
$$

$\left(\left(R_{\text {month_i }}^{\mathrm{NAT}}\right)_{W, A, D}\right)$ is the monthly natural runoff for wet, average and dry years under natural conditions. 
Flood regimes were defined by the flow components (magnitude, duration and seasonality) of habitual $\left(\mathrm{Q}_{5} \%\right)$, geomorphologic (or bankfull discharge $)\left(\mathrm{Q}_{G L}\right)$ and connectivity floods $\left(\mathrm{Q}_{\text {CONEC }}\right)$ in increasing order of magnitude and return period and as flow events that guarantee biologic, geomorphologic and connectivity functionality, respectively (Martínez and Fernández, 2006b). Drought regimes were determined by the characteristics of null and minimum flows taken from moving averages of seven consecutive days. Please see Magdaleno (2009) for a detailed description of the methodology and an application to a particular case. This methodology is used by the CEDEX and the Spanish Environmental Ministry to evaluate the degree of flow regime alterations in different basins in Spain and in the determination of environmental flows, impact assessment of dams and water management plans (Magdaleno \& Martínez, 2009).

Environmental flows were calculated for the Mula stream downstream of La Cierva reservoir and for the Perea stream downstream from the Caputa spring due to their importance in the aquatic resource management. Three different scenarios were considered depending on the exponent $(m)$ used to calculate the environmental variability factor $(1.5,2$ or 2.5 , from greater to lower flow regime conservation).

\section{RESULTS}

\section{Characterisation of natural flow regimes}

In its natural regime, the portion of the Mula stream that is downstream of the La Cierva reservoir presented a mean flow of $0.13 \mathrm{~m}^{3} / \mathrm{s}$ and a mean annual runoff of $4.17 \mathrm{hm}^{3}$, which varied between $0.33 \mathrm{hm}^{3}$ in dry years and $9.20 \mathrm{hm}^{3}$ in wet years (Table 4). This demonstrates the considerable inter-annual variations in flow, as the coefficient of variation (CV-inter) is 3.72 (Fig. 2). Intra-annual variation was also notable with peak flows in autumn and spring and minimum flows in summer. The annual mean maximum daily flow $\left(\mathrm{Q}_{C}\right)$ was $4.05 \mathrm{~m}^{3} / \mathrm{s}$, the habitual flood flow $\left(\mathrm{Q}_{5} \%\right)$ was $0.43 \mathrm{~m}^{3} / \mathrm{s}$, the geomorphologic flood
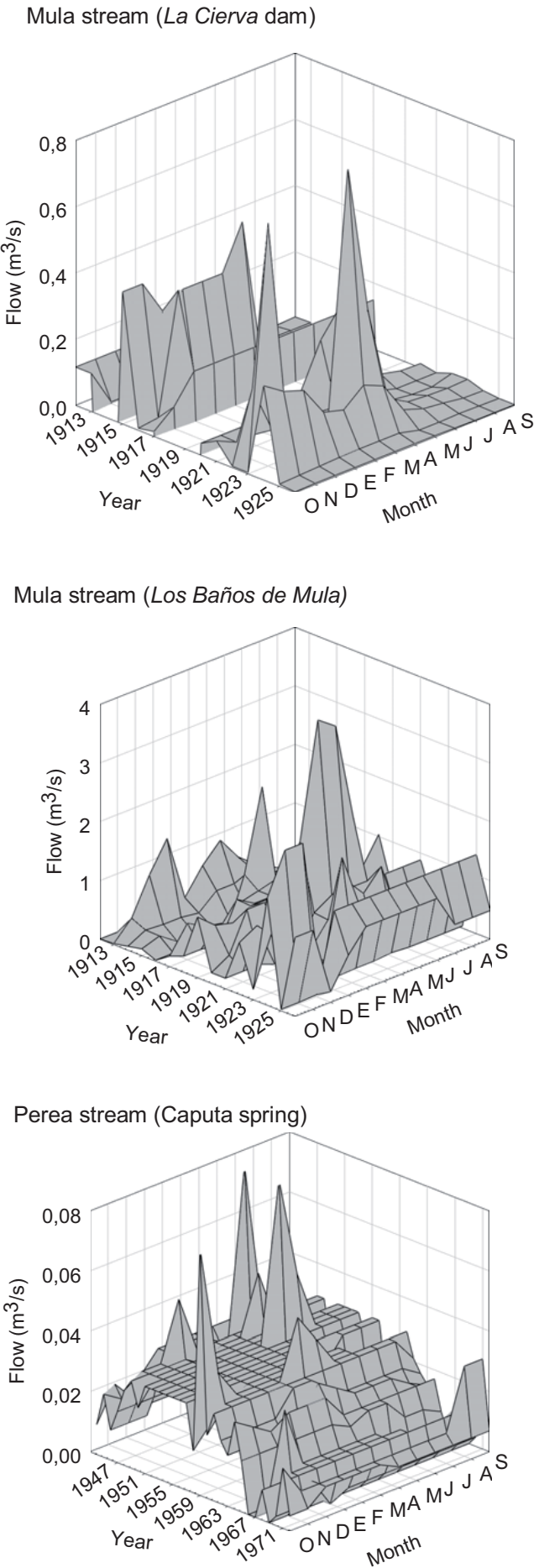

Figure 2. Inter- and intra-annual variation of mean daily flows of the natural flow series in the studied gauging stations. Variación inter- e intra-anual de los caudales medios diarios de la serie de caudales naturales en las estaciones de aforo estudiadas. 
flow $\left(\mathrm{Q}_{G L}\right)$ was $4.98 \mathrm{~m}^{3} / \mathrm{s}$, and the connectivity flow $\left(\mathrm{Q}_{C O N E C}\right)$ was $7.20 \mathrm{~m}^{3} / \mathrm{s}$, although the studied time series registered flows of up to $10.32 \mathrm{~m}^{3} / \mathrm{s}$. The mean annual minimum flow $\left(\mathrm{Q}_{s}\right)$ was $0 \mathrm{~m}^{3} / \mathrm{s}$, and the habitual drought flow during summer months $\left(\mathrm{Q}_{95} \%\right)$ was $0.01 \mathrm{~m}^{3} / \mathrm{s}$. This $\mathrm{Q}_{95} \%$ was not exceeded for a maximum of 75.2 consecutive days, with an average of 1.8 days per month of null flow recorded between May and September. At Los Baños de Mula, downstream of the confluence with the Pliego stream, the annual mean runoff was $18.40 \mathrm{hm}^{3}$, varying between 30.48 and $5.91 \mathrm{hm}^{3}$ in wet and dry years, respectively (CV-inter: 1.43$)$, with a mean daily flow of $0.58 \mathrm{~m}^{3} / \mathrm{s}$. The intra-annual variation pattern was very similar to that upstream, although it obviously presented higher monthly flows, flood flows and drought values (Table 4). Flows seldom reached null values, with a mean minimum flow of $0.09 \mathrm{~m}^{3} / \mathrm{s}$ and a $\mathrm{Q}_{95} \%$ of $0.1 \mathrm{~m}^{3} / \mathrm{s}$.

The Perea stream (Caputa spring) presented a lower mean annual runoff $\left(0.89 \mathrm{hm}^{3}\right)$ and a reduced inter-annual variation range $\left(1.37 \mathrm{hm}^{3}\right.$ in wet years and $0.41 \mathrm{hm}^{3}$ in dry years). The intra-annual variation pattern showed both the expected maximum flows in spring and autumn and the minimums in summer, although with a lower seasonal variation. The mean daily flow was $0.03 \mathrm{~m}^{3} / \mathrm{s}$, with small habitual floods $\left(\mathrm{Q}_{5} \%=0.05 \mathrm{~m}^{3} / \mathrm{s}\right)$ and drought values reaching a minimum value of $0.01 \mathrm{~m}^{3} / \mathrm{s}$ during approximately two months (August and September) (Table 4).

Table 4. Hydrologic indicators of the natural flow regimes of the Mula and Perea streams. Indicadores hidrológicos del regimen natural de caudal de los ríos Mula y Perea.

\begin{tabular}{|c|c|c|c|c|c|}
\hline Component & Aspect & Parameter & $\begin{array}{c}\text { Mula stream } \\
\text { (La Cierva dam) }\end{array}$ & $\begin{array}{c}\text { Mula stream } \\
\text { (Los Baños de Mula) }\end{array}$ & $\begin{array}{c}\text { Perea stream } \\
\text { (Caputa spring) }\end{array}$ \\
\hline \multirow{13}{*}{$\begin{array}{l}\text { HABITUAL } \\
\text { VALUES }\end{array}$} & \multirow{4}{*}{$\begin{array}{l}\text { Magnitude (mean of annual } \\
\text { runoffs in } \mathrm{hm}^{3} \text { ) }\end{array}$} & Wet year & 9.20 & 30.48 & 1.37 \\
\hline & & Average year & 3.57 & 18.63 & 0.90 \\
\hline & & Dry year & 0.33 & 5.91 & 0.41 \\
\hline & & Adjusted year & 4.17 & 18.40 & 0.89 \\
\hline & \multirow{4}{*}{$\begin{array}{l}\text { Variability of runoffs (difference } \\
\text { between monthly maximum and } \\
\quad \text { minimum runoff in } \mathrm{hm}^{3} \text { ) }\end{array}$} & Wet year & 3.08 & 4.84 & 0.44 \\
\hline & & Average year & 1.24 & 3.50 & 0.15 \\
\hline & & Dry year & 0.16 & 2.45 & 0.10 \\
\hline & & Adjusted year & 1.43 & 3.58 & 0.21 \\
\hline & \multirow{3}{*}{$\begin{array}{l}\text { Seasonality (month of maximum } \\
\text { and minimum runoff) }\end{array}$} & Wet year & NOV-JUL & OCT-SEP & APR-JUN \\
\hline & & Average year & APR-JUL & APR-SEP & DEC-SEP \\
\hline & & Dry year & OCT-SEP & NOV-FEB & NOV-SEP \\
\hline & \multirow{2}{*}{ Variability of flows $\left(\mathrm{m}^{3} / \mathrm{s}\right)$} & $\mathrm{Q}_{10 \%}$ & 0.22 & 1.26 & 0.03 \\
\hline & & $\mathrm{Q}_{90 \%}$ & 0.01 & 0.10 & 0.02 \\
\hline \multirow{7}{*}{$\begin{array}{l}\text { FLOOD } \\
\text { VALUES }\end{array}$} & \multirow{4}{*}{ Magnitude $\left(\mathrm{m}^{3} / \mathrm{s}\right)$} & Mean of maximum annual daily flows $\left(\mathrm{Q}_{C}\right)$ & 4.05 & 6.71 & 1.33 \\
\hline & & Geomorphologic flood flow $\left(\mathrm{Q}_{G L}\right)$ & 4.98 & 7.62 & 2.34 \\
\hline & & Conectivity flood flow $\left(\mathrm{Q}_{C O N E C}\right)$ & 7.20 & 10.70 & 3.77 \\
\hline & & Habitual flood flow $\left(\mathrm{Q}_{5} \%\right)$ & 0.43 & 1.53 & 0.05 \\
\hline & \multirow{2}{*}{ Variability } & $\mathrm{CV}\left(\mathrm{Q}_{C}\right)$ & 0.88 & 0.73 & 1.77 \\
\hline & & $\mathrm{CV}\left(\mathrm{Q}_{5} \%\right)$ & 1.26 & 0.67 & 0.71 \\
\hline & $\begin{array}{c}\text { Duration (maximum number of } \\
\text { consecutive days) }\end{array}$ & $\mathrm{Q}>\mathrm{Q}_{5} \%$ & 10.00 & 15.80 & 9.34 \\
\hline \multirow{5}{*}{$\begin{array}{l}\text { DROUGHT } \\
\text { VALUES }\end{array}$} & \multirow{2}{*}{ Magnitude $\left(\mathrm{m}^{3} / \mathrm{s}\right)$} & Mean annual minimum flow $\left(\mathrm{Q}_{s}\right)$ & 0.00 & 0.09 & 0.01 \\
\hline & & $\mathrm{Q}_{95 \%}$ & 0.01 & 0.10 & 0.01 \\
\hline & \multirow{2}{*}{ Variability } & $\mathrm{CV}\left(\mathrm{Q}_{s}\right)$ & 0.87 & 0.86 & 0.76 \\
\hline & & $\mathrm{CV}\left(\mathrm{Q}_{95} \%\right)$ & 0.90 & 0.85 & 0.61 \\
\hline & $\begin{array}{c}\text { Duration (maximum number } \\
\text { of consecutive days) }\end{array}$ & $\mathrm{Q}<\mathrm{Q}_{95} \%$ & 75.17 & 74.93 & 61.14 \\
\hline
\end{tabular}




\section{Flow regime alteration}

A progressive alteration of the flow regime of the Mula stream has taken place since the construction of La Cierva reservoir. In general, interand intra-annual variability has been reduced, and the natural hydrograph has been reversed: winter flows have fallen, whereas summer flows have increased (Fig. 3). Waters delivered by the dam were diverted directly to irrigation channels, leaving a dry bed downstream up to the confluence with the Pliego stream. At this point (Los

Mula stream (La Cierva dam)

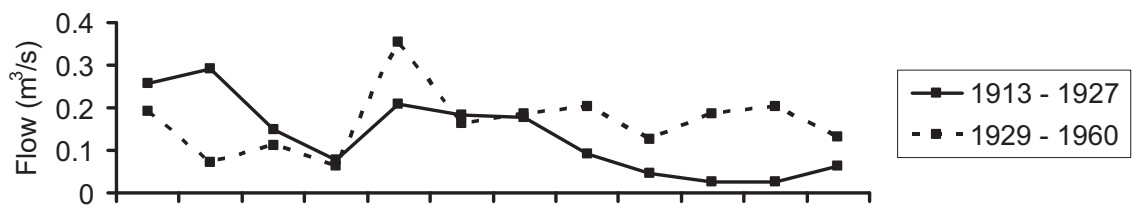

Oct Nov Dec Jan Feb Mar Apr May Jun Jul Ago Sep
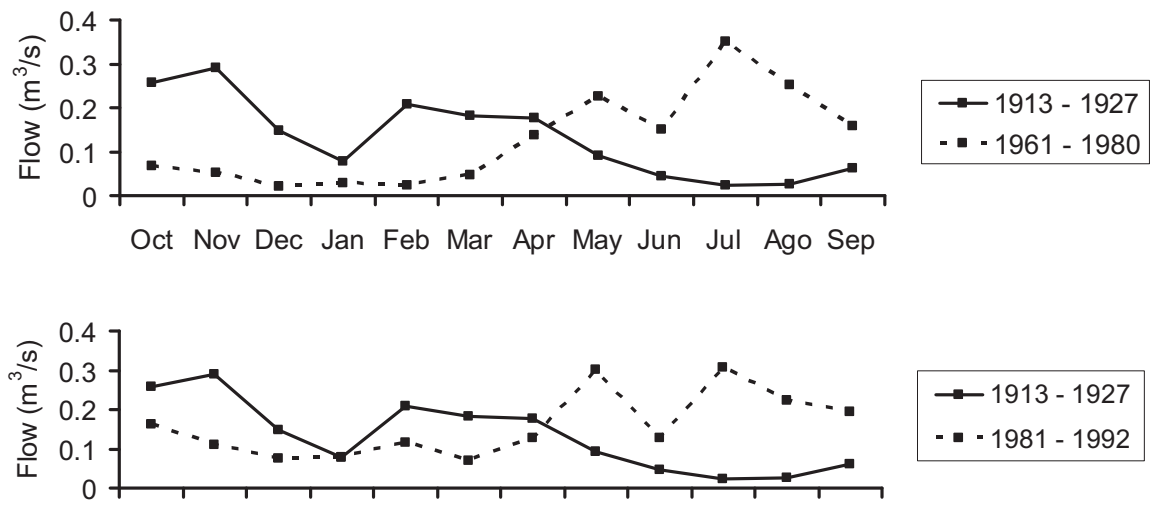

Oct Nov Dec Jan Feb Mar Apr May Jun Jul Ago Sep
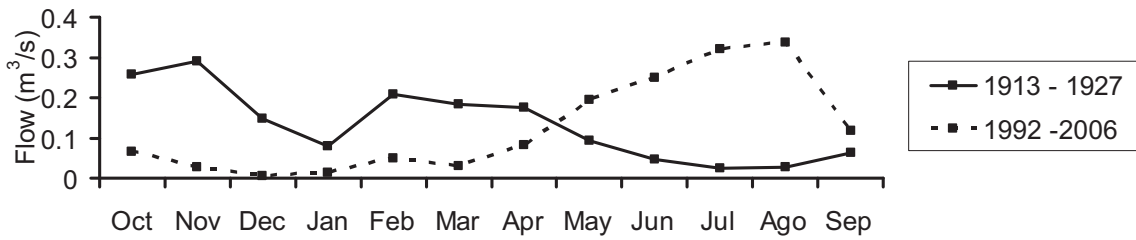

Mula stream (Los Baños de Mula)

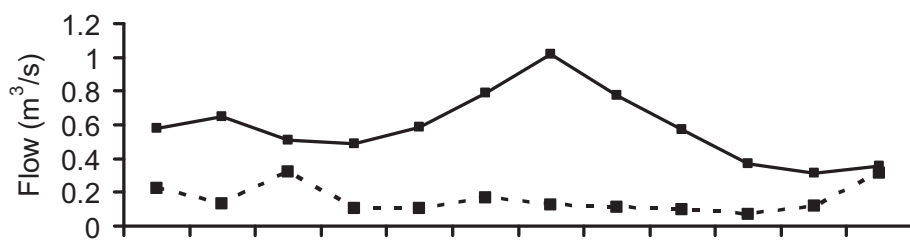

Oct Nov Dic Ene Feb Mar Abr May Jun Jul Ago Sep

Figure 3. Variation of mean monthly flows in the natural and altered regimes of the Mula stream at La Cierva reservoir and at Los Baños de Mula. Variabilidad de los caudales medios mensuales en los regímenes natural y alterado del río Mula en el embalse de La Cierva y en Los Baños de Mula. 
HABITUAL VALUES
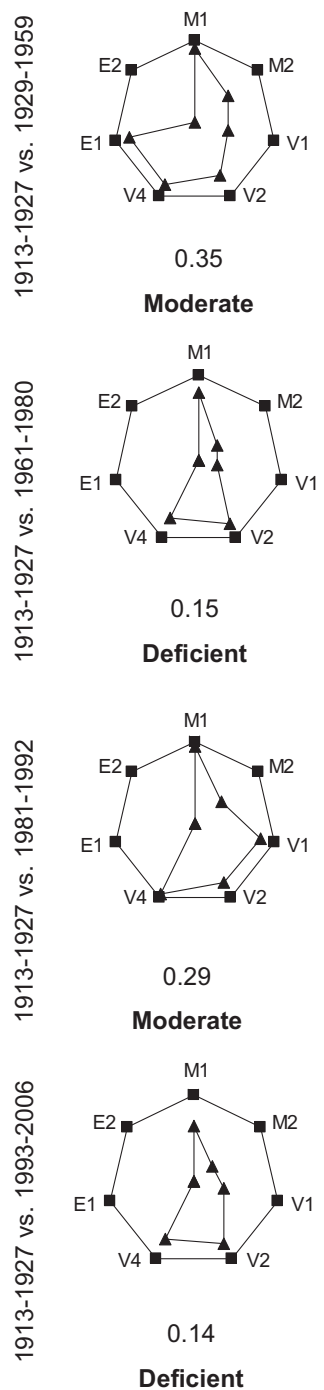

FLOOD VALUES
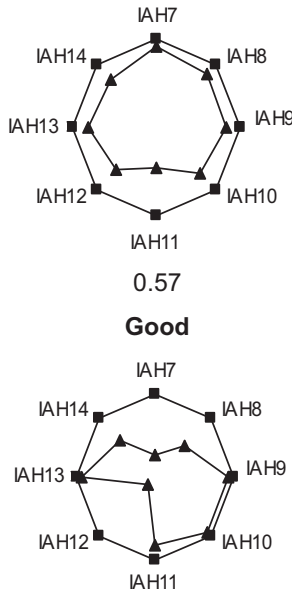

0.41

Good

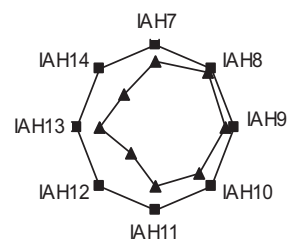

0.57

Good

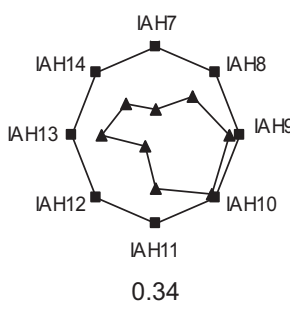

Moderate
DROUGHT VALUES

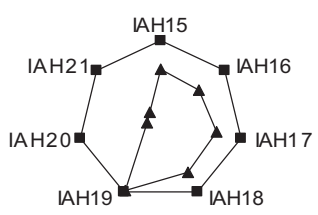

0.31

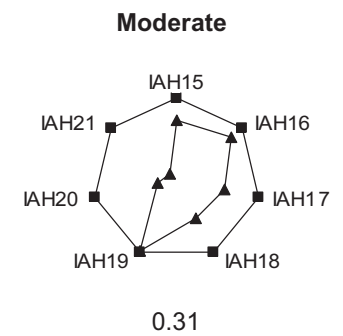

Moderate

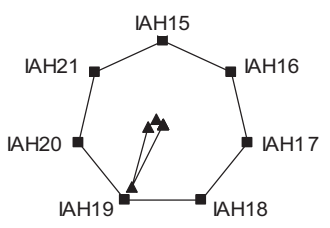

0.01

Very deficient

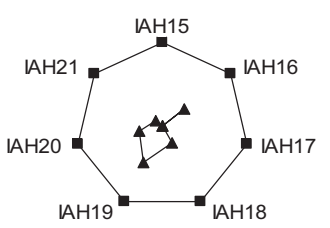

0.03

Very deficient

$\neg$ Altered regime

$\rightarrow$ Natural regime

Figure 4. Alterations, global alteration index and conservation status of the Mula stream at La Cierva reservoir for habitual, flood and drought values throughout the different stages studied. M1: Annual runoff magnitude, M2: Monthly runoff magnitude, V1: Annual runoff variability, V2: Monthly runoff variability, V4: Extreme variability, E1: Seasonal pattern of maximums, E2: Seasonal pattern of minimums, IAH7: Magnitude of maximum floods, IAH8: Magnitude of geomorphologic flow, IAH9: Magnitude of connectivity flow, IAH10: Magnitude of habitual floods, IAH11: Variability of maximum floods, IAH12: Variability of habitual floods, IAH13: Duration of floods, IAH14: Seasonal pattern of floods, IAH15: Magnitude of extreme droughts, IAH16: Magnitude of habitual droughts, IAH19: Duration of droughts, IAH20: Number of days with Q = 0, IAH21: Seasonal pattern of droughts. Alteraciones, índice de alteración global y estado de conservación en el río Mula en el embalse de La Cierva para valores habituales, de crecida y de sequía a través de los diferentes periodos estudiados. M1: escorrentía anual, M2: escorrentía mensual, V1: Variabilidad de la escorrentía anual, V2: Variabilidad de la escorrentía mensual, V4: Variabilidad extrema, E1: Patrón estacional de máximos, E2: Patrón estacional de mínimos, IAH7: Magnitud de las máximas crecidas, IAH8: Magnitud de del caudal geomorfológico, IAH9: Magnitud del caudal de conectividad, IAH10: Magnitud de las crecidas habituales, IAH11: Variabilidad de la crecidas máximas, IAH12: Variabilidad de las crecidas habituales, IAH13: Duración de las crecidas, IAH14: Patrón estacional de las crecidas, IAH15: Magnitud de las sequías extremas, IAH16: Magnitud de las sequías habituales, IAH19: Duración de las sequías, IAH20: Número de días con $Q=0$, IAH21: Patron estacional de sequías. 
Baños de Mula), the altered regime showed a drastic reduction of flows, but there was not a reversal in the seasonal pattern (Fig. 3).

During the first stage after the construction of the dam (1929-59), maximum discharges were recorded in February, May and August, which coincided with periods of irrigation. However, minimum discharges were observed from November to January (Fig. 3) because the water was retained in the reservoir. The dam radically changed the seasonal pattern of low flows and droughts, causing a great increase in the number of days with null flow. Flood values suffered less alteration; in contrast, the variability of maximum flows was the most altered parameter (Fig. 4).

After the 1960s (1961-80), the rise in irrigation demands by local farmers increased the pressure on superficial resources and intensified the operations of the dam. As a result, the alteration status for habitual values changed from moderate to deficient (Fig. 4). There was a significant reduction of flow magnitude and annual variability and an inversion of the seasonal pattern of maximum and minimum flows.

During the 1980s (1981-92), agricultural activity dropped slightly after a long drought, which lasted from 1978 to 1984 (Gómez-Espín et al., 2005). There was an improvement in the habitual and flood values, although drought values deteriorated to a very deficient state.
In the current stage (1993-2006), the irrigated area has increased considerably, to $41.48 \%$ (Table 2), as a consequence of water transfers from the Tagus River. However, this external source does not relieve the pressure on local supplies, and the alteration of certain aspects of the flow regime have intensified, resulting in deficient, moderate and very deficient states for habitual, flood and drought values, respectively (Fig. 4).

Similarly, the Pliego stream showed extremely low flows after the construction of the Pliego dam in 1993; it was dry for 352 days with a mean flow of $0.01 \mathrm{~m}^{3} / \mathrm{s}$ downstream from the dam.

\section{Environmental flow regime}

The annual runoff requirements estimated for the implementation of the EFRs for the Mula stream downstream of the La Cierva reservoir and the Perea stream in the three considered scenarios $(m=1.5, m=2$ and $m=2.5)$ are presented in Table 5. The mean monthly flow variations for wet, average and dry years are also depicted in figure $5(m=2)$.

In an acceptable conservation scenario $(m=2)$, the Mula stream requires an annual runoff of $1.35 \mathrm{hm}^{3}$ (37\% of the mean natural value) during average years, while the Perea stream requires less than half as much $\left(0.61 \mathrm{hm}^{3}, 86 \%\right.$ of the mean natural runoff). In the Mula stream, monthly

Table 5. Annual environmental requirements $\left(\mathrm{hm}^{3}\right)$ for the implementation of habitual flow regimes for the different conservation scenarios and type of year, and available resources for human uses. Volúmenes ambientales anuales ( $\mathrm{hm}^{3}$ ) necesarios para la implementación del regimen de caudales habituales para diferentes escenarios de conservación y tipo de año, y disponibilidad de recursos para uso humano.

\begin{tabular}{|c|c|c|c|c|c|}
\hline \multirow[b]{2}{*}{$m$} & \multirow[b]{2}{*}{ Type of year } & \multicolumn{2}{|c|}{ Mula stream (La Cierva dam) } & \multirow{2}{*}{$\begin{array}{c}\text { Perea stream } \\
\text { Environmental } \\
\text { requirement }\end{array}$} & \multirow{2}{*}{$\begin{array}{c}\text { (Caputa spring) } \\
\text { Available } \\
\text { resources }\end{array}$} \\
\hline & & $\begin{array}{c}\text { Environmental } \\
\text { requirement }\end{array}$ & $\begin{array}{l}\text { Available } \\
\text { resources }\end{array}$ & & \\
\hline \multirow{3}{*}{1.5} & wet & 5.05 & 4.35 & 0.94 & 0.03 \\
\hline & average & 1.86 & 1.79 & 0.64 & 0.07 \\
\hline & dry & 0.20 & 0.13 & 0.17 & 0.03 \\
\hline \multirow{3}{*}{2} & wet & 3.79 & 5.61 & 0.92 & 0.04 \\
\hline & average & 1.35 & 2.30 & 0.61 & 0.10 \\
\hline & dry & 0.16 & 0.17 & 0.16 & 0.05 \\
\hline \multirow{3}{*}{2.5} & wet & 3.22 & 6.18 & 0.91 & 0.05 \\
\hline & average & 1.12 & 2.53 & 0.59 & 0.11 \\
\hline & dry & 0.15 & 0.19 & 0.15 & 0.06 \\
\hline
\end{tabular}


Mula stream (La Cierva dam)

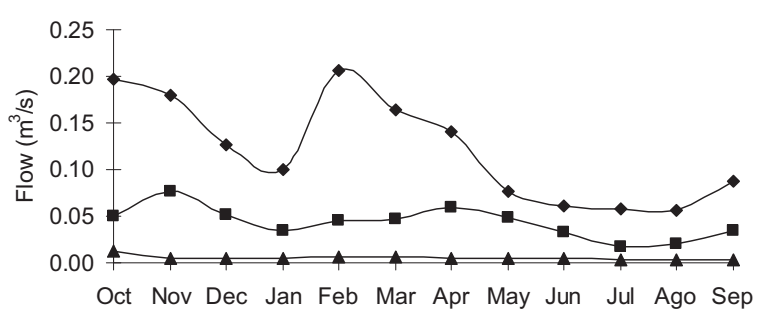

Perea stream (Caputa spring)

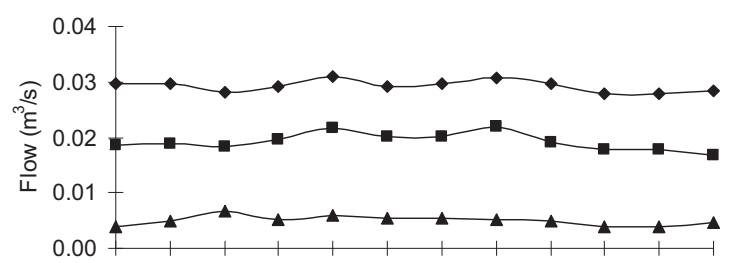

Oct Nov Dec Jan Feb Mar Apr May Jun Jul Ago Sep

$$
\multimap \text { Wet } \rightarrow \text { Average } \nrightarrow \text { Dry }
$$

Figure 5. Monthly variation of environmental flows obtained for wet, average and dry years to achieve an acceptable level of conservation of natural flow regime $(m=2)$. Variación mensual de los caudales ambientales obtenidos para que años húmedos, medios y secos alcancen un nivel aceptable de conservación del régimen natural $(\mathrm{m}=2)$.

flow variations follow the natural pattern of high fluctuations in wet years and lower fluctuations in average and dry years; however, higher flow constancy was observed in the Perea stream (Fig. 5).

Magnitude, period of return, seasonality, duration and rate of change of environmental geomorphological, connectivity and habitual flood estimations for both streams are presented in Table 6 . The environmental flood values obtained for the Mula stream must be delivered from the dam in March or April for habitual floods, in November for geomorphological floods and in October for connectivity floods. In extreme drought conditions, null flows during June, July and August downstream from the dam would be permitted.

When natural floods occurred in the Perea stream, only the runoff exceeding critical values of environmental floods could be diverted to the La Cierva reservoir. However, drought conditions could be more extreme than in the Mula be- cause the permitted consecutive days of null flows would be almost double, and the minimum flow permitted in $50 \%$ of the years would be almost a quarter of that established for the Mula (Table 6). The seasonal drought pattern would be delayed by one month (July, August and September).

\section{DISCUSSION}

The Mula stream is an excellent example of the strong hydrological alteration suffered by Mediterranean streams due to high water regulation by dams and excessive water abstraction for irrigation. Their natural flow regimes, characterised by considerable inter- and intra-annual variability with maximum flows in spring and autumn and minimums in summer, have been altered by the significant reduction of habitual and flood flows, longer drought periods and the reversal of the intra-annual variation pattern. These alterations have grown due to increasing water demands for irrigation purposes. This is due in part to the construction of regulation infrastructures such as La Cierva reservoir and external water supplies from the Tagus River. Presently, superficial water supplies cannot meet the existing demand. This has given rise to an increased dependence on ground water and external resources (more than $50 \%$ irrigation water resources) (Gomez-Espín et al. 2005).

In arid and semiarid areas, superficial and subterranean water abstraction and regulation by dams can significantly modify the frequency, magnitude and duration of floods and droughts (Thoms \& Sheldon, 2000). Many rivers in the Mediterranean basin are experiencing alterations to their natural regimes and drought frequencies similar to those reported here (Prat \& Ibáñez, 1995; Sánchez-Navarro et al., 2007; Sabater et al., 2009). Excessive water abstraction in Mediterranean streams impairs their capacity to support native biota. Impacts on fish assemblages have been documented recently in Catalonian rivers (Benejam et al., 2010), resulting in low native benthic species richness and population densities and their replacement by exotic watercolumn species at impacted sites. Overexploita- 
Table 6. Designed environmental flow regimes (flood and drought values). For habitual floods, "I" is the reference variable used to adjust the magnitude for every month by multiplying by the habitual flow established for that month (which depends on the selected scenario and the type of year). Régimen de caudales ambientales diseñado (para avenidas y sequías). Para avenidas habituales "I" es la variable de referencia utilizada para ajustar la magnitud para cada mes multiplicándola por el caudal habitual establecido para dicho mes (el cual depende del escenario seleccionado y del tipo de año).

\begin{tabular}{|c|c|c|}
\hline PARAMETERS & Mula stream (La Cierva dam) & Perea stream (Caputa spring) \\
\hline \multicolumn{3}{|l|}{ Flood values } \\
\hline \multicolumn{3}{|c|}{ Geomorphological floods $\left(Q_{G L}\right)$} \\
\hline \multicolumn{3}{|c|}{ Magnitude $\left(\mathrm{m}^{3} / \mathrm{s}\right)$} \\
\hline Excellent status & $>3.22$ & $>1.5$ \\
\hline Good status & $1.81-3.22$ & $0.84-1.50$ \\
\hline Return period (years) & 2.73 & 3.28 \\
\hline Seasonality & November & \\
\hline \multicolumn{3}{|l|}{ Duration and rate of change } \\
\hline If $\mathrm{Q}_{G L}>\left(\mathrm{m}^{3} / \mathrm{s}\right)$ & 5.02 & 2.34 \\
\hline Average duration (days) & 8.67 & \\
\hline \multicolumn{3}{|l|}{ Average rate of change } \\
\hline - Rise & 0.72 & \\
\hline - Fall & 0.29 & \\
\hline If $\mathrm{Q}_{G L}<\left(\mathrm{m}^{3} / \mathrm{s}\right)$ & 5.02 & 2.34 \\
\hline Average duration (days) & 10.83 & 4.61 \\
\hline \multicolumn{3}{|l|}{ Average rate of change } \\
\hline - Rise & 0.86 & 0.86 \\
\hline$\bullet$ Fall & 0.22 & 0.30 \\
\hline \multicolumn{3}{|l|}{ Conectivity floods $\left(Q_{c o n}\right)$} \\
\hline \multicolumn{3}{|l|}{ Magnitude $\left(\mathrm{m}^{3} / \mathrm{s}\right)$} \\
\hline Excellent status & $>5.08$ & $>2.57$ \\
\hline Good status & $2.86-5.08$ & $1.44-2.57$ \\
\hline Return period (years) & 5.47 & 6.58 \\
\hline Seasonality & October & October and December \\
\hline \multicolumn{3}{|l|}{ Duration and rate of change } \\
\hline If $\mathrm{Q}_{C O N E C T}>\left(\mathrm{m}^{3} / \mathrm{s}\right)$ & 7.93 & 4.01 \\
\hline Average duration (days) & 5.00 & 4.25 \\
\hline \multicolumn{3}{|l|}{ Average rate of change } \\
\hline - Rise & 0.60 & 0.70 \\
\hline - Fall & 0.25 & 0.08 \\
\hline If $\mathrm{Q}_{C O N E C T}<\left(\mathrm{m}^{3} / \mathrm{s}\right)$ & 7.93 & 4.01 \\
\hline Average duration (days) & 9.13 & \\
\hline \multicolumn{3}{|l|}{ Average rate of change } \\
\hline - Rise & 0.72 & \\
\hline - Fall & 0.29 & \\
\hline Habitual floods & & \\
\hline
\end{tabular}

Magnitude ("I" value)

October

13.72

6.22

November

9.55

8.03

December

8.44

8.14

January

11.43

4.02

February

13.56 
Table 6. (cont.)

\begin{tabular}{|c|c|c|}
\hline PARAMETERS & Mula stream (La Cierva dam) & Perea stream (Caputa spring) \\
\hline March & 6.11 & 3.52 \\
\hline April & 6.32 & 5.68 \\
\hline May & 12.94 & 4.44 \\
\hline June & 24.0 & 4.65 \\
\hline July & 54.58 & 4.14 \\
\hline August & 66.08 & 3.18 \\
\hline September & 78.78 & 10.54 \\
\hline Seasonality & March, April and November & April, May and October \\
\hline \multicolumn{3}{|l|}{ Duration and rate of change } \\
\hline Average duration (days) & 10.83 & 4.61 \\
\hline \multicolumn{3}{|l|}{ Average rate of change } \\
\hline - Rise & 0.86 & 0.86 \\
\hline - Fall & 0.22 & 0.30 \\
\hline \multicolumn{3}{|l|}{ Drought values } \\
\hline \multicolumn{3}{|l|}{ Consecutive null flows } \\
\hline \multicolumn{3}{|l|}{ Duration (days) } \\
\hline Threshold for $50 \%$ of years & 45.00 & 72.00 \\
\hline Maximum thresold & 88.00 & 170.00 \\
\hline Seasonality & June, July and August & July and August \\
\hline \multicolumn{3}{|l|}{ Non null flows } \\
\hline \multicolumn{3}{|l|}{ Magnitude $\left(\mathrm{m}^{3} / \mathrm{s}\right)$} \\
\hline 7-day Qmin for $50 \%$ of years & 0.04 & 0.01 \\
\hline Minimum threshold & 0.00 & 0.00 \\
\hline Seasonality & June, July and August & July, August and September \\
\hline
\end{tabular}

tion of aquifers can change upwelling reaches to downwelling and severely impact intermittent streams, reducing the base flow that feeds sources.

An increase in the frequency or severity of droughts may be the principal threat for the conservation of freshwater biodiversity in the Mula stream. This is especially true in downstream dam reaches that are dry during most of the year, thus converting natural intermittent reaches into ephemeral ones. This alteration can produce both direct and indirect effects on stream ecosystems. Marked direct effects include water loss, habitat loss for aquatic organisms and reduced stream connectivity. Indirect effects include the deterioration of water quality, alteration of food resources and changes in the strength and structure of interspecific interactions (Lake, 2003). Thus, a critical step in environmental flow setting is to ensure that the restored flow regime does not contain extended periods of extreme low flow or no flow and to implement low flows at the natural time of year.

Success in preserving the biodiversity and natural functions of our rivers depends on our capacity to protect and restore the main features of natural flow regimes. However, there is a serious methodological problem involved in characterising natural flow regimes, which also affects the determination of the environmental regime: the paucity and the unreliability of the data collected by the gauging stations (Baeza \& Vizcaíno, 2008). In this study, the 15 years of daily discharge data used to characterise the natural regime of the Mula stream were enough to be used in hydrologic analyses (Kennard et $a l ., 2010)$ and the Perea stream showed a broad and comprehensive series (1942-1971). However, pre-dam flow data were not available for the Pliego stream, and it was impossible to determine 
its environmental flow regime. Due to the dominance of karsts in the headwater of the Pliego stream and the importance of groundwater in its base flow, an environmental flow regime similar to that estimated for the Perea stream could be considered, although it would be of greater magnitude in relation to its larger drainage area.

The hydrological methods employed in this study (Martínez and Fernández, 2008a, b) have several advantages in that they: (1) take into account the typical interannual flow variability of Mediterranean streams, characterising different flow regimes for wet, average and dry years; (2) consider flows and droughts, the key flow regime elements of intermittent streams; (3) measure both quantitative and qualitative degrees of flow alteration; and (4) do not provide a single regime, but a set of possible environmental scenarios (depending on how close they come to the natural regime), and thus provide a useful tool for decision-makers. One disadvantage of hydrological methods is that they represent the minimum requirements of stream ecosystems without consideration of the environmental requirements of natural species and their habitats (Magdaleno, 2009). It is thus advisable to use additional methods such as habitat simulation, as recommended by the Hydrological Planning Instruction (2008), or a holistic approach, such as the ELOHA framework (Poff et al., 2010). Given the complex interrelationships of natural systems, the best possible use of the designed regimes is to perform a follow-up of the practical effects of the implemented flow regimes on the ecological status of the river ecosystem, applying the principle of adaptable management to rectify faults and guarantee the original objectives.

Implementation of environmental flows in the Mula stream necessitates guaranteeing these flows before water is used for other purposes (RDL 1/2001), restricting water abstraction to environmental thresholds and therefore reconciling the environmental and economic functions of water. Habitual environmental flows estimated at $L a$ Cierva require between $30 \%$ and $60 \%$ of the mean natural runoff, depending on the type of year and protection scenario considered, which must include the quantities required for simula- tion of floods. Available superficial resources for irrigation (Table 5) in all environmental scenarios studied are insufficient to meet the current demands of $29.07 \mathrm{hm}^{3}$ (Confederación Hidrográfica del Segura, 2008). Therefore, its implementation requires an intensive negotiation process within the communities of irrigators and other water users.

\section{ACKNOWLEDGEMENTS}

This work was financed by a pre-doctoral scholarship from the Universidad de Murcia awarded to Óscar Belmar Díaz. We wish to express our gratitude to the CEDEX for their attention and to Carolina Martínez for her assistance with IAHRIS software.

\section{BIBLIOGRAPHY}

BAEZA, D., F. MARTÍNEZ-CAPEL \& D. GARCÍA DE JALÓN, D. 2003. Variabilidad temporal de caudales: aplicación a la gestión de ríos regulados. Ingeniería del Agua, 10(4): 469-478.

BAEZA, D.\& P. VIZCAÍ́NO. 2008. Estimación de caudales ecológicos en dos cuencas de Andalucía. Uso conjunto de aguas superficiales y subterráneas. Ecosistemas, 17(1): 24-36.

BENEJAM, L., P. L. ANGERMEIER, A. MUNNÉ \& E. GARCÍA-BERTHOU. 2010. Assessing effects of water abstraction on fish assemblages in Mediterranean streams. Freshwater Biology, 55: 628-642.

CONFEDERACIÓN HIDROGRÁFICA DEL SEGURA. 2007. Estudio General sobre la Demarcación Hidrográfica del Segura. Ministerio de Medio Ambiente. 359 pp.

CONFEDERACIÓN HIDROGRÁFICA DEL SEGURA. 2008. Esquema Provisional de Temas Importantes. Ministerio de Medio Ambiente. 188 pp.

GÓMEZ-ESPÍN, J. M., E. GIL MESEGUER \& R. GARCÍA MARÍN. 2005. Insuficiencias hídricas y modernización de regadíos en la cuenca de Mula. Papeles de Geografía, 41-42: 101-121.

GÓMEZ ESPÍN, J. M., E. GIL MESEGUER \& R. GARCÍA MARÍN. 2006. El antes y después de la modernización de regadios. La experiencia de Mula. Colección Usos del Agua en el Territorio. 
Universidad de Murcia. 133 pp.

KENNARD, M. J., S. J. MACKAY, B. J. PUSEY, J. D. OLDEN \& N. MARSH. 2010. Quantifying uncertainty in estimation of hydrologic metrics for hydrological studies. River Research and Applications, 26: 137-156.

LAKE, P. S. 2003. Ecological effects of perturbation by drought in flowing waters. Freshwater Biol., 48: 1161-1172.

LÓPEZ-BERMÚDEZ, F. 1972. El agua en la cuenca del Segura. Papeles de Geografía, 4: 9-24.

LYTLE, D. A. \& N. L. POFF. 2004. Adaptation to natural flow regimes. Trends in Ecology and Evolution, 19(2): 94-100.

MAGDALENO, F. 2005. Caudales ecológicos: conceptos, métodos e interpretaciones. Monografía CEDEX. Ministerio de Fomento. Madrid. 194 pp.

MAGDALENO, F. 2009. Manual técnico de cálculo de caudales ambientales. Colegio de Ingenieros de Caminos, Canales y Puertos. Monografías de Medio Ambiente. Madrid. 88 pp.

MAGDALENO, F. \& R. MARTÍNEZ. 2009. CEDEX protocols for the assessment of the hydrogeomorphological quality of fluvial systems. Actas del Seminario PHAM (Physical Habitat Assesment Methods in Rivers), Instituto de Hidráulica Fluvial de Cantabria, Santander, España. 25 pp.

MARTÍNEZ, C. \& J. A. FERNÁNDEZ. 2006a. Índices de alteración hidrológica en ecosistemas fluviales. Monografía CEDEX. Ministerio de Fomento. Madrid. 178 pp.

MARTÍNEZ, C. \& J. A. FERNÁNDEZ. 2006b. Régimen ambiental de caudales (RAC): Metodología para la generación de escenarios, criterios para su valoración y pautas para su implementación. Actas del V Congreso Ibérico de Gestión y Planificación del Agua, Universidad de Algarbe, Faro, Portugal, $11 \mathrm{pp}$.

NAVARRO, T. M. 2007. Los instrumentos de gestión del Dominio Público Hidráulico. Estudio especial del contrato de cesión de derechos al uso privativo de las aguas y de los bancos públicos del agua, $1^{\text {st }}$ ed. Valencia-Murcia: Tirant Lo Blanch monografías-edit.um. 421 pp.

PRAT, N. \& C. IBÁÑEZ. 1995. Effects of water transfers projected in the Spanish national hydrological plan on the ecology of the lower river Ebro (N. E. Spain) and its Delta. Water Sci. Technol., 31: 7986.
POFF, N. L., J. D. ALLAN, M. B. BAIN, J. R. KARR, K. L. PRESTEGAARD, B. D. RICHTER, R. E. SPARKS \& J. C. STROMBERG. 1997. The natural flow regime. A paradigm for river conservation and restoration. Bioscience, 47: 769-784.

POFF, N. L., B. D. RICHTER, A. H. ARTHINGTON, S. E. BUNN, R. J. NAIMAN, E. KENDY, M. ACREMAN, C. APSE, B. P. BLEDSOE, M. C. FREEMAN, J. HENRIKSEN, R. B. JACONSON, J. G. KENNEN, D. M. MERRIT, J. H. O'KEEFFE, J. D. OLDEN, K. ROGERS, R. E. THARME \& A. WARNER. 2010. The ecological limits of hydrologic alteration (ELOHA): a new framework for developing regional environmental flow standards. Freshwater Biology, 55: 147-170.

POFF, N. L. \& J. K. H. ZIMMERMAN. 2010. Ecological responses to altered flow regimes: a literature review to inform the science and management of environmental flows. Freshwater Biology, 55: 194-205.

SABATER, S., M. J. FEIO, M. A. S. GRAÇA, I. MUÑOZ \& A. M. ROMANÍ. 2009. The Iberian Rivers. In: Rivers of Europe. K. Tockner, U. Uehlinger \& C. T. Robinson (eds.): 113-149. Academic Press, London, UK.

SÁNCHEZ-NAVARRO, R., M. STEWARDSON, P. BREIL, D. GARCÍA DE JALÓN \& M. EISELE. 2007. Hydrological impacts affecting endangered fish species: a Spanish case study. River Research and Applications, 23: 511-523.

STANFORD, J. A. \& J. V. WARD. 1979. Stream regulation in North America. In: The ecology of regulated streams. J. V. Ward \& J. A. Stanford (eds.): 215-236. Plenum Press. New York, USA.

THOMBS, M. C. \& F. SHELDON. 2000. Water resource development and hydrological change in a large dryland river: The Barwon-Darling river, Australia. Journal of Hydrology, 228: 10-21.

VIDAL-ABARCA, M. R., M. L. SUÁREZ \& R. GÓMEZ. 2002. Caudales y aportaciones en la cuenca del Segura: ¿Son significativos los datos hidrológicos? Actas del III Congreso Ibérico de Gestión y Planificación del Agua. Sevilla, España. $10 \mathrm{pp}$.

VIDAL-ABARCA, M. R. \& M. L. SUÁREZ. 2007. Un modelo conceptual sobre el funcionamiento de los ríos mediterráneos sometidos a perturbaciones naturales (riadas y sequías). Limnetica, 26(2): 227292. 